Jurnal Pendidikan Dasar Perkhasa
http://jurnal.stkippersada.ac.id/jurnal/index.php/JPDP/

\title{
PENGEMBANGAN MEDIA KARTU DOMINO UNTUK MENINGKATKAN MOTIVASI BELAJAR SISWA KELAS IV SD
}

\author{
Atikah Muthoharoh*1, Tety Nur Cholifah² \\ 1,2Fakultas Ilmu Pendidikan, Universitas Islam Raden Rahmat Malang \\ Diterima: 03 Oktober 2020. Dipublikasi: 30 Oktober 2020.
}

\begin{abstract}
The purpose of this study is determine the feasibility of domino card learning media in thematic learning and find out the suitability of domino cards to increase learning motivation of fourth grade elementary school students. This research is development research using the Borg and Gall model. The research was conducted at SDN Permanu 02 with the subject of 33 fourth grade students for the 2019/2020 school year. The results showed the feasibility of domino card learning media based on material validation, media validation, group response trials and large group student response trials getting an average rating of $89 \%$ with very valid qualifications. The results of student learning motivation in small groups showed the percentage before 58\%with enough categories, after the percentage of $89 \%$ with very high category.The results of student learning motivation in large groups showed before the percentage of $39 \%$ with the low categoryand after percentage of $76 \%$ with high category. Based on the data mentioned above, it can be concluded that the domino card learning media is suitable for use in the learning process and can increase the learning motivation of grade IV SD students.
\end{abstract}

Keywords: Learning media, Domino cards, Learning motivation

Abstrak. Tujuan penelitian ini yaitu mengetahui kelayakan media pembelajaran kartu domino dalam pembelajaran tematik dan mengetahui kesesuaian kartu domino untuk meningkatkan motivasi belajar siswa kelas IV SD pada materi hebatnya cita-citaku. Penelitian ini merupakan penelitian pengembangan (R\&D) dengan model Borg and Gall. Penelitian dilakukan di SDN Permanu 02 dengan subjek 33 siswa kelas IV tahun ajaran 2019/2020. Hasil penelitian menunjukkan kelayakan media pembelajaran kartu domino berdasarkan validasi materi, validasi media, uji coba respon kelompok dan uji coba respon siswa kelompok besar mendapatkan rata-rata penilaian sebesar $89 \%$ dengan kualifikasi sangat valid. Hasil motivasi belajar siswa dalam kelompok kecil menujukkan hasil persentase before sebesar 58\% persentase after sebesar $89 \%$ dengan kategori sangat tinggi. Peningkatan motivasi belajar siswa sebesar $31 \%$. Hasil motivasi belajar siswa dalam kelompok besar menujukkan hasil persentase before sebesar 39\% dalam kategori kurang dan persentase after sebesar 76\% dalam kategori tinggi. Berdasarkan data di atas, dapat disimpulkan bahwa media pembelajaran kartu domino layak digunakan dalam proses pembelajaran serta dapat meningkatkan motivasi belajar siswa kelas IV SD.

Kata kunci: Media pembelajaran, Kartu domino, Motivasi belajar

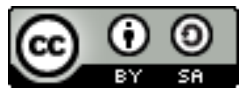

\section{Pendahuluan}

$$
\text { Kurikulum } 2013 \text { merupakan }
$$

kurikulum yang berbasis tematik

integrasi, dimana dalam kurikulum ini tidak ada pemisahan antarmata pelajaran. Artinya beberapa mata

pelajaran dipadukan menjadi satu dan

* surel korespondensi: atikahmuthoharoh@gmail.com 
tidak terpisah-pisah. Menurut Fernandes (2017: 3) ciri-ciri atau karakteristik pembelajaran tematik yaitu (1) Berpusat pada siswa (2) Memberikan pengalaman lansung pada siswa (3) Pemisahan antar pelajaran tidak nampak (4) Menyajikan konsep dari berbagai mata pelajaran dalam suatu proses pembelajaran (5) Bersifat luwas (Fleksibel) (6) Hasil belajar dapat berkembang sesuai dengan minat dan kebutuhan siswa. Penerapan kurikulum 2013 yang dirasa masih baru, ada beberapa kendala yang dialami oleh sekolah, guru, maupun peserta didik. Hal ini sejalan dengan pendapat Asrohah (2013: 42) pelaksanaan kurikulum 2013 masih repot hal ini karena kurang nya alat dan fasilitas yang mendukung pembelajaran. Kendala-kendala yang dialami oleh setiap lembaga tentu berbeda. Fasilitas dalam pembelajaran yang dimaksud salah satunya yaitu media pembelajaran.

Kustandi \& Sutjipto (2011:9) menyebutkan bahwa media pembelajaran adalah alat yang dapat membantu proses belajar mengajar dan berfungsi untuk memperjelas makna pesan yang disampaikan, tujuan pembelajaran dapat tercapai. Sedangkan menurut Falahudin (2014: 7) media pembelajaran adalah alat bantu pembelajar dalam mengajar serta sarana pembawa pesan dari sumber belajar ke penerima pesan belajar (pebelajar). Media pembelajaran terdiri dari 2 unsur penting yaitu perangkat lunak (isi) dan perangkat keras (wujud media). Dapat disimpulkan media pembelajaran adalah alat yang digunakan untuk menyampaikan pesan pembelajaran dari guru kepada siswa untuk mencapai tujuan pembelajaran. Media pembelajaran yang dapat digunakan dalam pembelajaran sangat beragam. Menurut Kustandi \& Sutjipto (2011: 79), jenis-jenis media pembelajaran ada 3 yaitu media audio, media visual dan media audio visual. Para ahli mengklasifikasikan media dengan sudut pandang yang berbeda, karena perkembangan teknologi yang semakin pesat. Hal ini menyebabkan jenis-jenis media yang dapat digunakan untuk pembelajaran pun semakin banyak.

$$
\text { Manfaat praktis media }
$$

pembelajaran dalam proses belajar mengajar menurut Arsyad (2011: 15) 
yaitu (1) Media pembelajaran dapat membantu keefektifan proses pembelajaran dan memperjelas penyajian pesan dan informasi. (2) Membangkitkan motivasi dan minat siswa. (3) Media pembelajaran dapat membantu siswa dalam meningkatkan pemahaman (4) Media pembelajaran dapat membantu menyajikan informasi dengan menarik dan terpecaya. Salah satu manfaat media pembelajaran yaitu dapat membangkitkan motivasi dan minat siswa dalam belajar. Motivasi belajar merupakan dorongan yang ada dalam diri siswa untuk melakukan suatu aktifitas belajar. Dorongan tersebut bisa berasal dari dalam diri siswa sendiri dan dari lingkungan belajar siswa. Adanya dorongan untuk belajar menjadikan tujuan pembelajaran mudah tercapai. Hal ini menunjukkan bahwa motivasi berperan besar dalam usaha mencapai tujuan pembelajaran. Hal ini sesuai dengan fungsi motivasi menurut Sardiman (2012: 85) ada 3 yaitu (1) Mendorong manusia untuk berbuat(2) Menentukan arah perbuatan (3) Menyeleksi perbuatan.

Motivasi belajar berperan penting dalam proses pembelajaran. Menurut Fathurrohman (Saputra,
2018: 37) cara meningkatkan motivasi belajar siswa adalah (1) Menjelaskan tujuan pembelajaran kepada peserta didik (2) Hadiah (3) Saingan/ kompetisi (4) Pujian (5) Hukuman (6) Memberikan perhatian maksimal ke peserta didik (7) Membentuk kebiasaan belajar yang baik (8) Membantu kesulitan belajar peserta didik, baik secara individual maupun kelompok (9) Menggunakan metode yang bervariasi (10) Menggunakan media pembelajaran yang baik, dan sesuai dengan tujuan pembelajaran. Motivasi belajar dapat ditumbuhkan dengan berbagai cara salah satunya yaitu pembelajaran dengan menggunakan media pembelajaran yangyang baik dan sesuai dengan tujuan pembelajaran. Salah satu cara yang dapat digunakan yaitu dengan pembelajaran menggunakan media pembelajaran yang menarik dan melibatkan siswa dalam penggunaannya. Media pembelajaran yang menarik dapat memicu rasa ingin tahu siswa sehingga motivasi dapat dimunculkan berdasarkan rasa ingin tahu tersebut.Berdasarkan wawancara kepada guru kelas IV SD Negeri Permanu 02 penerapan kurikulum 2013 yang sudah berjalan 2 
tahun terakhir ini di SD Negeri Permanu 02 mengalami beberapa kendala. Kendala tersebut diantaranya yaitu dalam hal fasilitas. Fasilitas yang kurang memadai sehingga dalam penerapan kurikulum 2013 kurang maksimal. Fasilitas yang dimaksud dalam hal ini diantaranya bahan ajar, media pembelajaran serta lingkungan yang mendukung siswa dalam belajar. Pembelajaran tematik di kelas IV SD Negeri Permanu 02 menggunakan sumber belajar berupa buku Lembar Kerja Siswa (LKS) penerbit yang sudah disesuaikan dengan buku tema berdasarkan ketentuan pemerintah. Sumber belajar buku LKS tersebut kemudian dikembangkan oleh guru dengan menambah materi yang belum ada di dalam buku.Kemampuan anak Kelas IV SDN Pemanu 02 adalah 80\% di bawah rata-rata. Metode mengajar guru kelas IV adalah metode konvensional dengan media pembelajaran seadanya. Hal ini karena media pembelajaran dan sumber belajar yang masih terbatas.

Berdasarkan observasi, didapati bahwa pembelajaran berlangsung secara berkelompok. Metode yang digunakan adalah metode konvensional dengan sumber belajar berupa buku LKS dan penjelasan guru, dengan menggunakan media pembelajaran papan tulis. Karakteristik siswa merupakan anakanak dengan semangat belajar yang kurang. Hal ini di tunjukkan dengan sikap mereka yang kurang antusias dalam pembelajaran, suka bergurau dengan temannya ketika pembelajaran berlangsung, serta berjalan-jalan ke tempat temannya ketika guru menjelaskan atau guru sedang memberikan tugas.

Salah satu cara untuk mengatasi kurangnya media pembelajaran yang dapat memicu semangat belajar siswa yaitu dengan mengembangkan suatu media pembelajaran yang melibatkan siswa dalam penggunaannya. Salah satu media pembelajaran yang dapat digunakan yaitu media pembelajaran kartu domino. Kartu domino adalah sebuah kertas tebal yang berukuran kecil yang terdapat garis tengah yang membagi antara ruas kanan dan ruas kiri, biasanya berisikan titik besar ditiap ruas kartu yang jumlahnya berbeda antara 0-6 titik pada tiap ruas.

Media pembelajaran kartu domino sebagai media pembelajaran merupakan modifikasi dari kartu 
domino berupa kartu yang terdiri dari 2 ruas kanan dan kiri. Salah satu ruas untuk pertanyaan dan ruas berikutnya untuk jawaban. Pertanyaan dan jawaban kartu domino pembelajaran berada dalam kartu yang berbeda. Jadi, dalam permainannya siswa harus (secara bergantian) mengurutkan kartu tersebut menjadi satu kesatuan yang runtut sesuai dengan soal dan jawabannya. Media pembelajaran kartu domino dalam penelitian ini mengalami modifikasi bentuk dan materi pelajaran. Bentuk dari kartu domino dalam penelitian ini yaitu trapesium sama kaki dengan 2 ruas. Bentuk trapesium akan menjadikan kartu domino yang dimainkan siswa menjadi menarik dan unik. Siswa bermain dengan cara menghubungkan kartu satu dengan kartu berikutnya hingga menjadi sebuah bangun persegi panjang. Materi yang termuat dalam kartu domino ini yaitu materi pembelajaran tematik kelas IV Sekolah Dasar.

Sesuai dengan karakter siswa yang lebih senang berkomunikasi dengan temannya serta lebih menyukai bermain, maka media pembelajaran berupa kartu domino merupakan salah satu alternatif yang dapat digunakan untuk menarik perhatian siswa. Hal ini sesuai dengan pendapat Purnama (2019: 3) bahwa bermain dengan anak usia dini diibaratkan seperti 2 sisi mata uang. Sisi satu dan yang lainnya saling melengkapi dan tidak dapat dipisahkan karena bermain merupakan dunia anak-anak. Bermain adalah aktifitas yang sangat menyenangkan bagi anak.Penggunaan media pembelajaran kartu domino sebagai media pembelajaran dapat menjadikan anak bermain sambil belajar.

Berdasarkan permasalah di atas maka dalam penelitian ini yang menjadi pokok permasalahan adalah kurangnya media pembelajaran serta motivasi belajar siswa yang rendah. Maka peneliti mengambil judul penelitian "Pengembangan Media Pembelajaran Kartu Domino untuk Meningkatkan Motivasi belajar Siswa kelas IV SD".

\section{Metode}

Penelitian ini termasuk dalam penelitian pengembangan atau yang dikenal dengan Research and Development). Prosedur penelitian yang akan digunakan dalam penelitian 
dan pengembangan ini mengacu dan pengembangan menurut Borg and kepada langkah-langkah penelitian Gall seperti terlihat pada Gambar 1.

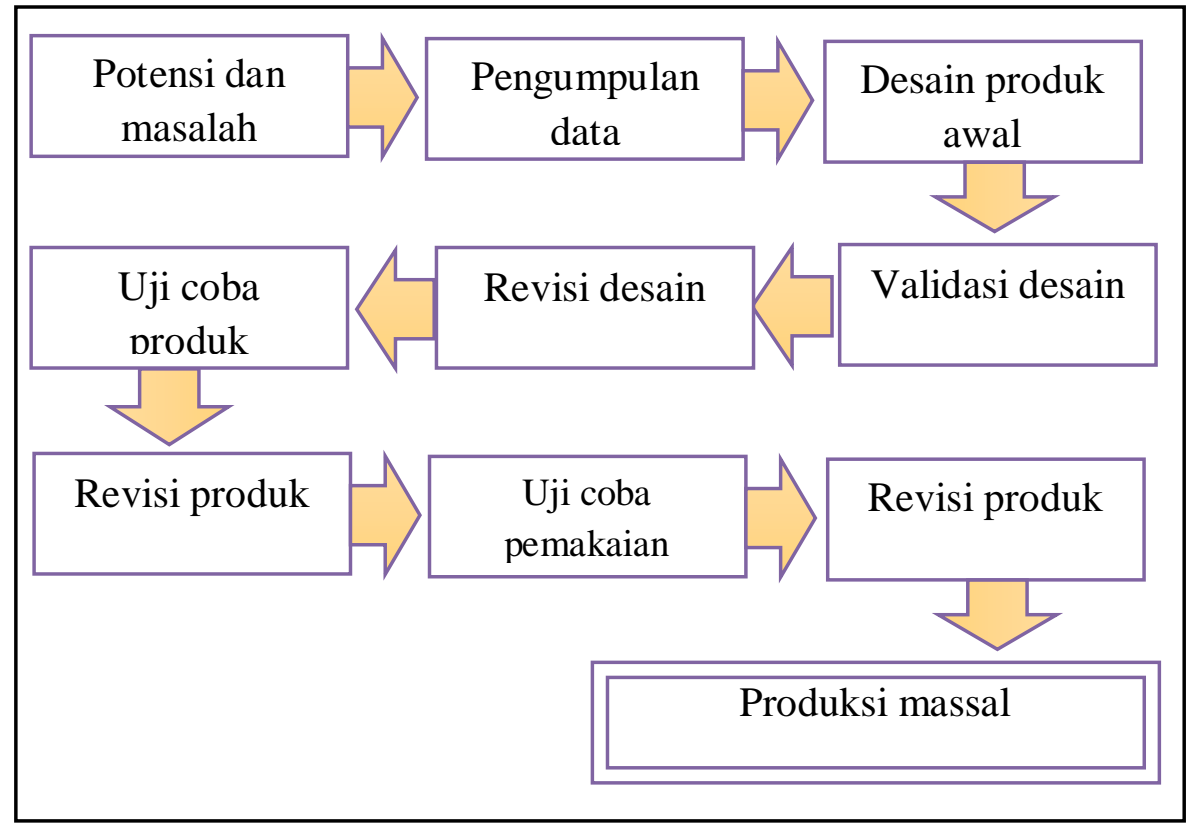

Gambar 1. Langkah-langkah Penelitian dan Pengembangan Borg and Gall

Pengembangan media efektifitas media pembelajaran yang pembelajaran dalam penelitian ini digunakan dalam meningkatkan hanya dilakukan sampai langkah ke 9 motivasi belajar siswa. Eksperimen dikarenakan produksi massal dapat dilakukan dengan cara membutuhkan waktu dan biaya yang membandingkan keadaan sebelum cukup banyak.

Menurut Sugiyono (2017: 415) pengujian dapat dilakukan dengan eksperimen, yaitu membandingkan dan sesudah menggunakan media pembelajaran kartu domino (beforeafter). desainl ekperimen dapat dilihat pada Gambar 2.

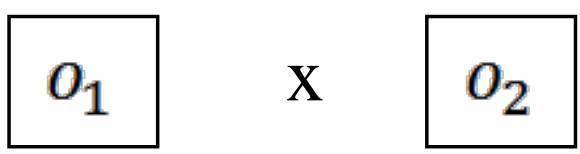

Gambar 2. Desain eksperimen (before-after). $O_{1}$ nilai sebelum treatment dan $\mathrm{O}_{2}$ nilai sesudah treatment

Uji coba dilakukan dalam dua tahap yaitu uji coba dalam kelompok kecil dengan subjek uji coba 5 siswa kelas IV sekolah dasar dan uji coba 
dalam kelompok besar dengan subjek uji coba 33 siswa kelas IV SDN Permanu 02.

Teknik pengumpulan data dalam peneitian ini yaitu wawancara, observasi, angket dan dokumentasi. Teknik analisis data terdiri dari dua macam yaitu sebagai berikut.

1) Kelayakan Media

Analisis kelayakan media dilakukan kepada 3 responden yaitu

$$
P=\frac{\sum x}{\sum x i} \times 100 \%
$$

Dimana P : kelayakan; $\sum x$ : jumlah ditentukan kelayakannya sesuai jawaban yang diperoleh; dan $\Sigma x i$ : dengan kualifikasi dalam tabel seperti jumlah jawaban maksimal. terlihat dalam Tabel 1.

Hasil yang diperoleh dari

hitungan persentase kemudian

Tabel 1. Kualifikasi Tingkat kelayakan Berdasarkan Tingkat Persentase

\begin{tabular}{cccc}
\hline No. & Rentang Prosentase $\%$ & Kualifikasi & Kriteria Kelayakan \\
\hline 1. & $84<$ skor $\leq 100$ & Sangat Valid & Tidak perlu direvisi \\
2. & $68<$ skor $\leq 84$ & Valid & Tidak perlu revisi \\
3. & $52<$ skor $\leq 68$ & Cukup Valid & Perlu Revisi \\
4. & $36<$ skor $\leq 52$ & Kurang Valid & Revisi \\
5. & $0 \leq$ skor $\leq 36$ & Sangat Kurang Valid & Revisi \\
\hline
\end{tabular}

2) Motivasi Belajar Siswa

Peningkatan motivasi belajar siswa setelah menggunakan media pembelajaran kartu domino. Angket motivasi belajar

ahli materi, ahli media dan siswa. Pengolahan data penilaian dilakukan dengan cara mendeskripsikan semua pendapat, saran, dan tanggapan dari responden. Sedangkan data yang berbentuk angka dianalisis dengan persentase, menggunakan rumus sebagai berikut (Arikunto, 2003: 313). 
kriteria penilaian seperti terlihat pada Tabel 2.

Tabel 2. Pedoman Kriteria Penilaian skala 1-5 Motivasi Belajar

\begin{tabular}{cll}
\hline No. & Interval & Kategori \\
\hline 1. & $81-100$ & Sangat Tinggi \\
2. & $61-80$ & Tinggi \\
3. & $41-60$ & Cukup \\
4. & $21-40$ & Kurang \\
5. & $0-20$ & Kurang Sekali \\
\hline
\end{tabular}

Keseluruhan skor yang diperoleh dalam rumus persentase berikut siswa kemudian di masukkan ke (Mardhani, 2017:99).

$$
\text { Persentase penilaian }=\frac{\text { skor yang diperoleh }}{\text { skor maksimal }} \times 100 \%
$$

Selanjutnya dilakukan uji t dengan rumus paired sample (uji $\mathrm{t}$ berpasangan). Paired sample t-test digunakan untuk menguji perbedaan pada dua sampel dengan subjek yang sama namun mengalami dua perlakuan yang berbeda pada situasisebelum dan sesudah proses. Pengujian dilakukan dengan bantuan aplikasi SPSS 25 for windows 10 dengan rumus analyze - Compare Means - Paired-Samples T Test dengan pengambilan keputusan menurut Zaakiyah (2017: 70) sebagai berikut:

a) Jika nilai sig. (2 Tailed) $<0,05$, maka terdapat perbedaan yang signifikan antara motivasi belajar siswa pada data before dan after.

b) Jika nilai sig. (2 Tailed) $>0,05$, maka tidak terdapat perbedaan yang signifikan antara motivasi belajar siswa pada data before dan after.

\section{Hasil dan Pembahasan}

Pada penelitian ini data yang diperoleh berupa data kualitatif dan data kuantitatif. Data kualitatif berupa hasil wawancara, observasi dan pendapat dan saran validator yang dideskripsikan. Data kuantitatif berupa hasil angket kelayakan media dan angket motivasi belajar berupa angket before-after dengan menggunakan skala likert 1-5. Data penelitian diuraikan sebagai berikut.

1. Kelayakan Media

Kelayakan media di uji validitas kepada 2 ahli yaitu ahli materi dan ahli media. Uji validitas bertujuan 
untuk mengetahui kelayakan media kartu domino dari sudut pandang ahli. Selanjutnya produk kartu domino diuji cobakan kepada siswa dalam skala kecil dan besar. Hal ini bertujuan untuk mengetahui kemenarikan media kartu domino dari sudut pandang siswa. Data hasil kelayakan media dapat dilihat pada Tabel 3.

Tabel 3. Rekapitulasi Data Hasil Kelayakan Media

\begin{tabular}{clcccc}
\hline No. & Pengambilan Data & $\sum_{x}$ & $\sum_{x i}$ & Persentase & Kualifikasi \\
& & 40 & 50 & $80 \%$ & Valid \\
\hline 1. & Validasi Materi & 97 & 100 & $97 \%$ & Sangat Valid \\
\hline 2. & Validasi Media & 335 & 375 & $89 \%$ & Sangat Valid \\
\hline 3. & Uji Coba Kelompok Kecil & 2171 & 2475 & $88 \%$ & Sangat Valid \\
\hline 4. & Uji Coba Kelompok Besar & & $\mathbf{8 9 \%}$ & Sangat Valid \\
\hline \multicolumn{6}{c}{ Rata-rata Persentase } \\
\hline \multicolumn{6}{c}{}
\end{tabular}

Berdasarkan Tabel 3 dapat

diketahui bahwa kelayakan media pembelajaran kartu domino berdasarkan ahli materi $80 \%$ dengan kualifikasi valid, ahli media 97\% dengan kualifikasi sangat valid, uji respon siswa kelompok kecil 89\% dengan kualifikasi sangat valid dan uji coba kelompok besar 88\% dengan kualifikasi sangat valid. Hasil kelayakan media dapat dilihat dalam Gambar 3.

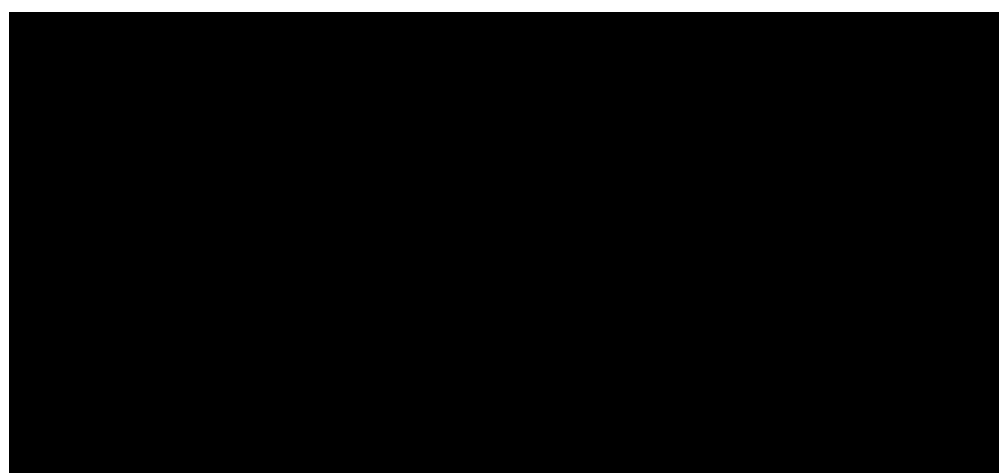

Gambar 3. Persentase Hasil Kelayakan Media disimpulkan bahwa media domino dalam penelitian ini pembelajaran kartu domino valid dan layak digunakan dalam pembelajaran.

2. Motivasi Belajar Siswa dikembangkan untuk meningkatkan motivasi belajar siswa kelas IV Sekolah Dasar. Eksperimen dilakukan dengan cara membandingkan 
motivasi sebelum dan sesudah motivasi belajar siswa yang menggunakan media pembelajaran diperoleh. kartu domino (before-after). Indikator motivasi belajar siswa terdiri dari 4 indikator yaitu (1) Adanya hasrat dan keinginan berhasil (2) Adanya dorongan dan kebutuhan belajar mendapat persentase (3) Adanya harapan dan cita-cita masa depan (4) Adanya kegiatan yang menarik dalam belajar. Berikut adalah hasil data

1. Motivasi Belajar Siswa Kelompok Kecil

Pengambilan data motivasi belajar dilakukan sebelum dan sesudah pembelajaran menggunakan media pembelajaran kartu domino. Hasil data motivasi belajar siswa kelompok kecil before-after, dapat dilihat pada Tabel 4.

Tabel 4. Data Motivasi Belajar Siswa Kelompok Kecil

\begin{tabular}{clcccc}
\hline No. & Nama & $\begin{array}{c}\text { Skor Sebelum } \\
\text { (before) }\end{array}$ & Kategori & $\begin{array}{c}\text { Skor Sesudah } \\
\text { (After) }\end{array}$ & Kategori \\
\hline 1. & Mufidatul Khoirot & 53 & Cukup & 90 & Sangat tinggi \\
2. & Nayla Mufida Ma'ruf & 51 & Cukup & 90 & Sangat tinggi \\
3. & Afifah Defiana Eka Putri & 59 & Cukup & 88 & Sangat tinggi \\
4. & Ahmad Taqiyudin Zuhdi & 73 & Tinggi & 89 & Sangat tinggi \\
5. & Azka Zada Badru Z & 53 & Cukup & 85 & Sangat tinggi \\
\hline \multicolumn{7}{c}{ Jumlah Maksimal } & $\mathbf{2 8 9}$ & $\mathbf{4 4 2}$ & \\
\hline \multicolumn{7}{c}{ Persentase } & $\mathbf{5 0 0}$ & $\mathbf{5 0 0}$ & Sangat tinggi \\
\hline \multicolumn{7}{c}{ Persentase kenaikan } & $\mathbf{3 0 \%}$ & $\mathbf{8 8 \%}$ & \\
\hline
\end{tabular}

Selanjutnya yaitu dilakukan uji $\mathrm{t}$ uji $\mathrm{t}$ dapat dilihat dalam tabel untuk menguji perbedaan data SPSS seperti terlihat pada Tabel 5. pada data before dan after. Hasil

Tabel 5. Paired Sample T Test Kelompok Kecil

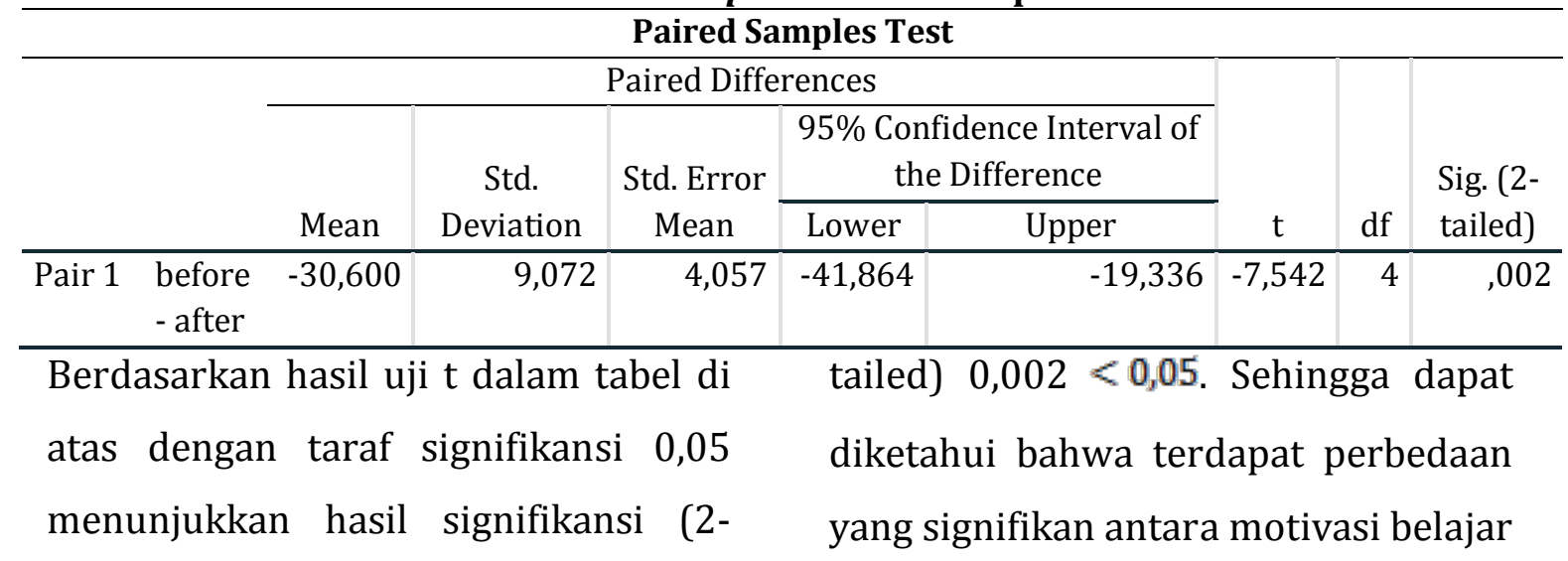


siswa pada data before dan after. Sehingga dapat disimpulkan bahwa media pembelajaran kartu domino dapat meningkatkan motivasi belajar siswa kelas IV Sekolah dasar dalam uji coba kelompok kecil, sehingga produk media dapat diuji cobakan dalam kelompok besar.

1. Motivasi Belajar Siswa
Kelompok Besar

Pengambilan data motivasi belajar siswa dalam kelompok besar dilakukan setelah pengambilan data motivasi belajar siswa dalam kelompok kecil.Motivasil belajar siswa kelompok besar dilakukan kepada 33 siswa kelas IV SDN Permanu 02. Berikut adalah hasil data motivasi belajar siswa dalam kelompok besar seperti telihat pada Tabel 6.

Tabel 6. Data Motivasi Belajar Siswa Kelompok Besar

\begin{tabular}{|c|c|c|c|c|c|}
\hline No. & Nama Siswa & before & Kategori & After & Kategori \\
\hline 1. & Laila Nur Habibah & 29 & Kurang & 71 & Tinggi \\
\hline 2. & Agil Muhammad Erdin & 69 & Tinggi & 91 & Sangat Tinggi \\
\hline 3. & Firmansyah & 28 & Kurang & 75 & Ttinggi \\
\hline 4. & Galih Wisnu Anugrah & 24 & Kurang & 70 & Tinggi \\
\hline 5. & Lutfi Anggraeni & 26 & Kurang & 78 & Tinggi \\
\hline 6. & Muhammad Erfan M & 29 & Kurang & 79 & Tinggi \\
\hline 7. & Muhammad Rivki A & 26 & Kurang & 74 & Tinggi \\
\hline 8. & Rio Dwi Pratama & 70 & Tinggi & 79 & Tinggi \\
\hline 9. & Rivo Artha Wijaya & 69 & Tinggi & 80 & Tinggi \\
\hline 10. & Wendra Rasfian & 40 & Cukup & 77 & Tinggi \\
\hline 11. & Ahmad Ghozali & 35 & Kurang & 73 & Tinggi \\
\hline 12. & Alfiatus Sa'adah & 36 & Kurang & 81 & Sangat tinggi \\
\hline 13. & Anindia Heni Rahma M & 27 & Kurang & 70 & Tinggi \\
\hline 14. & Aprilia Khabibatul R & 29 & Kurang & 73 & Tinggi \\
\hline 15. & Davit Dwi Prakoso & 72 & Tinggi & 80 & Tinggi \\
\hline 16. & Dea Cantika Putri S & 67 & Tinggi & 81 & Sangat tinggi \\
\hline 17. & Dwi Ariani Puspitasari & 68 & Tinggi & 76 & Tinggi \\
\hline 18. & Icha Maulidia RJ & 35 & Kurang & 78 & Tinggi \\
\hline 19. & Karisma Nizaroh Qusita & 37 & Kurang & 78 & Tinggi \\
\hline 20. & Lathifatul Arifah & 27 & Kurang & 70 & Tinggi \\
\hline 21. & Moch Habib Apriliawan & 38 & Kurang & 87 & Sangat tinggi \\
\hline 22. & Muhammad Nizar Aldi R & 35 & Kurang & 71 & Tinggi \\
\hline 23. & Muhimatul Khofshoh S & 25 & Kurang & 57 & Cukup \\
\hline 24. & Puput Pujiasih & 35 & Kurang & 71 & Tinggi \\
\hline 25. & Ridho Agustian & 34 & Kurang & 76 & Tinggi \\
\hline 26. & Riko Ardiansyah & 54 & Cukup & 80 & Tinggi \\
\hline 27. & Robet Alfarizi & 23 & Kurang & 74 & Tinggi \\
\hline 28. & Satriyo Wibowo & 36 & Kurang & 69 & Tinggi \\
\hline 29. & Sofya Yuni Anggraini & 33 & Kurang & 76 & Tinggi \\
\hline 30. & Ubaidillah As’ad & 37 & Kurang & 75 & Tinggi \\
\hline 31. & Wahyu Arofiq & 30 & Kurang & 76 & Tinggi \\
\hline 32. & Sifak Maulinda & 40 & Cukup & 75 & Tinggi \\
\hline
\end{tabular}




\begin{tabular}{ccccc} 
33. Andre Khoirul Setiawan & 38 & Kurang & 74 & Tinggi \\
\hline Jumlah & $\mathbf{1 3 0 1}$ & $\mathbf{2 4 9 5}$ & \\
\hline Presentase & $\mathbf{3 9 \%}$ & Kurang & $\mathbf{7 6 \%}$ & Tinggi \\
\hline Persentase Peningkatan & & $\mathbf{3 7 \%}$ & \\
\hline
\end{tabular}

Selanjutnya yaitu dilakukan uji t untuk menguji perbedaan data pada data before dan after. Hasil
Uji t dapat dilihat dalam tabel

SPSS seperti pada Tabel 7 .

Tabel 7.Paired Sample T Test Kelompok Besar

\begin{tabular}{|c|c|c|c|c|c|c|c|c|}
\hline \multicolumn{9}{|c|}{ Paired Samples Test } \\
\hline & \multicolumn{5}{|c|}{ Paired Differences } & \multirow[b]{3}{*}{$\mathrm{t}$} & \multirow[b]{3}{*}{$\mathrm{df}$} & \multirow{3}{*}{$\begin{array}{l}\text { Sig. (2- } \\
\text { tailed) }\end{array}$} \\
\hline & \multirow[b]{2}{*}{ Mean } & \multirow{2}{*}{$\begin{array}{c}\text { Std. } \\
\text { Deviation }\end{array}$} & \multirow{2}{*}{$\begin{array}{l}\text { Std. } \\
\text { Error } \\
\text { Mean }\end{array}$} & \multicolumn{2}{|c|}{$\begin{array}{l}95 \% \text { Confidence Interval } \\
\text { of the Difference }\end{array}$} & & & \\
\hline & & & & Lower & Upper & & & \\
\hline $\begin{array}{ll}\text { Pair } & \text { before - } \\
1 & \text { after }\end{array}$ & $-36,182$ & 13,092 & 2,279 & $-40,824$ & $-31,540$ & $-15,876$ & 32 & 000 \\
\hline
\end{tabular}

Berdasarkan hasil uji t dalam tabel di disimpukan bahwa media atas dengan taraf signifikansi 0,05 pembelajaran kartu domino pada menunjukkan hasil signifikansi (2materi hebatnya cita-citaku dapat tailed) $0,000<0,05$. Sehingga dapat meningkatkan motivasi belajar siswa diketahui bahwa terdapat perbedaan yang signifikan antara motivasi belajar siswa kelompok besar pada data before dan after. Berdasarkan data pada kelompok besar.

Peningkatan motivasi belajar siswa dalam kelompok kecil dan besar dapat dilihat dalam Gambar 4. yang telah disebutkan di atas dapat

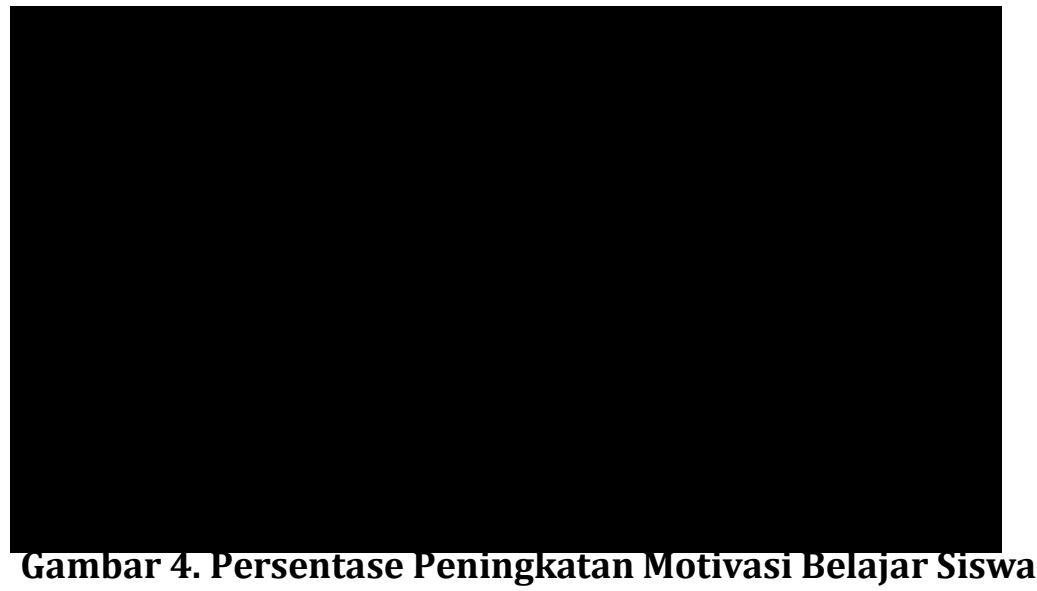


Berdasarkan Gambar 4,

Media pembelajaran kartu diperoleh kelayakan media pembelajaran kartu domino berdasarkan hasil validasi materi (aspek kelayakan isi, bahasa dan penggunaan) sebesar $80 \%$ dengan kategori valid, validasi ahli media (tampilang, penggunaan dan penyajian) $97 \%$ dengan kategori sangat valid, hasil uji respon siswa (aspek tampilan, efektifitas dan ketepatan produk) dalam kelompok kecil 89\% dan hasil uji respon siswa kelompok besar sebesar 88\%. Ratarata keseluruhan kelayakan media pembelajaran kartu domino yaitu 89\% dengan kualifikasi sangat valid. Hal ini menunjukkan bahwa media pembelajaran kartu domino layak untuk digunakan dalam proses pembelajaran. Senada dengan pendapat Isnadia (2016: 21) dalam penelitiannya yang menyebutkan bahwa kelayakan media pembelajaran dilakukan kepada ahli materi, ahli media dan diujicobakan kepada siswa. Berdasarkan pendapat Sugiyono (2008: 93) media pembelajaran dikualifikasikan sangat valid jika mempereloh skor dalam rentang $84-100$. penelitian bertujuan untuk meningkatkan motivasi belajar siswa. Berdasarkan Gambar 4 motivasi belajar siswa dalam kelompok kecil yaitu 5 siswa kelas IV Sekolah dasar sebelum belajar menggunakan kartu domino adalah 58\% dengan kategori cukup. Selanjutnya motivasi belajar siswa setelah menggunakan kartu domino adalah 88\% dengan kategori sangat tinggi. Kemudian dilakukan uji coba kepada kelompok besar yaitu kepada 33 siswa kelas IV SDN Permanu 02 dengan hasil motivasi belajar sebelum menggunakan media kartu domino yaitu 39\% dengan kategori rendah, kemudian motivasi belajar siswa setelah belajar menggunakan kartu domino yaitu 76\% dengan kategori tinggi. Berdasarkan data tersebut dapat disimpulkan bahwa media pembelajaran kartu domino dapat meningkatkan motivasi belajar siswa kelas IV Sekolah Dasar.

Pendapat di atas sesuai dengan pendapat Rasyid (2017: 29) dalam penelitiannya yang menyatakan bahwa siswa yang telah belajar menggunakan kartu domino 
menyatakan sangat senang dan lebih giat (termotivasi) dalam mengerjakan soal menggunakan kartu domino. Pendapat yang sesuai juga dikemukakan oleh Sumini (2019:185) yang menyatakan bahwa penggunaan kartu domino dianggap efektif karena dapat menciptakan suasana belajar yang menyenangkan. Siswa dalam melakukan permainan menggunakan kartu domino ada aturan-aturan yang harus dipatuhi. Permainan menggunakan kartu domino ada yang menang dan ada yang kalah, dengan demikian siswa akan merasa tertantang dan menumbuhkan jiwa kompetisi dalam dirinya. Pendapat serupa pula dikemukakan oleh Heksani (2012: 8) pembelajaran menggunakan media kartu dominomelibatkan siswa secara aktif dalam proses pembelajaran dan menumbuhkan minat serta motivasi siswa untuk belajar.

Pembelajaran

menggunakan kartu domino merupakan pembelajaran dengan melibatkan siswa dalam penggunaannya. Pembelajaran dengan menggunakan kartu domino dapat menciptakan suasana belajar yang menyenangkan karena siswa belajar sambil bermain. Hal ini sesuai dengan karakteristik siswa Sekolah Dasar yang masih lekat dengan bermain. Belajar sambil bermain menggunakan kartu domino melibatkan siswa dalam belajar, bergerak, berkelompok serta dalam praktik penggunaannya. Hal ini sesuai dengan pendapat Alim (2009: 82) yang menyebutkan bahwa karakteristik anak usia Sekolah Dasar yaitu (1) senang bermain (2) seenang bergerak (3) senang beraktifitas dalam kelompok (4) senang praktik langsung.

\section{Simpulan}

Berdasarkan data yang telah diperoleh media pembelajaran kartu domino valid dan layak digunakan sebagai media pembelajaran dengan perolehan data yang berasal dari validasi materi, validasi media dan uji coba kelompok kecil dan besar dengan rata-rata persentase sebesar $89 \%$ dengan kualifikasi sangat valid. Pembelajaran menggunakan kartu domino dapat meningkatkan motivasi belajar siswa. Data motivasi belajar kelompok kecil yaitubefore 58\% dan after $88 \%$. Hasil uji t dengan taraf signifikansi 0,05 menunjukkan hasil signifikansi (2-tailed) $0,002<0,05$. 
Sehingga dapat diketahui bahwa terdapat perbedaan yang signifikan antara motivasi belajar siswa pada data before dan after. Data motivasi belajar kelompok besar yaitu before $39 \%$ dan after $76 \%$. Hasil uji t dengan taraf signifikansi 0,05 menunjukkan hasil signifikansi (2-tailed) 0,000 $<0,05$. Sehingga dapat diketahui bahwa terdapat perbedaan yang signifikan antara motivasi belajar siswa pada data before dan after. Berdasarkan pemaparan data diatas dapat disimpulkan bahwa media pembelajaran kartu domino valid dan layak digunakan dalam pembelajaran serta dapat meningkatkan motivasi belajar siswa kelas IV Sekolah Dasar.

\section{Daftar Pustaka}

Alim, A. (2009). Permainan Mini Tenis untuk Pembelajaran Pendidikan Jasmani Olaraga dan kesehatan Siswa di sekolah Dasar. JPJL. 6 (2), 82.

Arsyad, A. (2011). Media Pembelajaran. PT Raja Grafindo Persada, Jakarta.

Arikunto, S. (2003). Dasar-dasar Evaluasi Pendidikan. Bumi Aksara, Jakarta.

Asrohah, H dan Anas, A,A. (2013). Pengembangan
Kurikulum.Kopertais IV Press, Surabaya.

Falahudin, I. (2014). Pemanfaatan Media dalam Pembelajaran.Jurnal Lingkar Widyaiswara,1 (4),7.

Fernandes, J. (2017). Penerapan Pembelajaran Tematik Kelas Rendah SDN 1 Blunyahan, Sewon, Bantul, Yogyakarta.Jurnal Pendidikan Guru Sekolah Dasar, 9(6),3.

Heksani, MY. (2012). Penggunaan Media Kartu Domino-Kwartet (Domtet) DalamPembelajaranKeterampil an Berbicara Bahasa Jerman Siswa Kelas XI Bahasa SMA Negeri 1 Tumpang. Jurnal.

Kustandi, C. \& Sutjipto, B. (2011). Media Pembelajaran: Manual dan Digital. Ghalia Indonesia, Bogor.

Isnadia, Siti CZ. (2016). Kelayakan Multimedia Pembelajaran pada Materi Menggambar Pola Rok untuk Siswa SMP Negeri 1 Tonjong. (Skripsi). Semarang: Universitas Negerii Semarang.

Mardhani, A. W. (2017). Pengembangan Media Pembelajaran Permainan Ular Tangga Akuntansi Untuk Meningkatkan Motivasi Belajar Kompetensi Mengelola Kartu Piutang Kelas XI Keuangan Smk Muhammadiyah 1 Prambanan Klaten Tahun Ajaran 2016/2017. (Skripsi). Yogyakarta: Universitas Negeri Yogyakarta. 
Purnama, S. (2019). Pengembangan Alat Permainan Edukatif Anak Usia Dini. PT Remaja Rosdakarya, Bandung.

Rasyid, I. K. S., Rohani. (2018). Manfaat Media dalam Pembelajaran, AXIOM,7(1),28.

Saputra, J.A. (2018). Peningkatan Motivasi Belajar Melalui Penerapan Media Gambar Pada Mata Pelajaran IPS kelas IX di MTs Putra Islahuddin kediri tahun pelajaran 2017/2018.(Skripsi). Mataram: Universitas Islam Negeri.

Sardiman.(2012). Interaksi dan Motivasi Belajar Mengajar. PT Raja Grafindo Persada, Jakarta.
Sumini. (2019). Penggunaan Media Edukatif Kartu DominoUntuk Meningkatkan Hasil Belajar MatematikaSiswa Kelas VII MTs Negeri Dumai.Jurnal Pendidikan dan Pengajaran. 3 (1). 185.

Sugiyono. (2008). Metode Penelitian Kuantitatif, Kualitatif dan R\&D. CV Alfabeta, Bandung.

Sugiyono.(2017). Metode penelitian pendidikan. Alfabeta, Bandung.

Zaakiyah, E.D., Abas, A., \& Udin, S., (2017). Efektivitas Model Pembelajaran NumberedHeads-together. TARBAWY, 4 (1),70. 